\title{
МЕТОДИКА РОЗВИТКУ МЕТОДИЧНОЇ КОМПЕТЕНТНОСТІ ВИКЛАДАЧІВ ВІЙСЬКОВО- СПЕЦІАЛЬНИХ ДИСЦИПЛІН У СИСТЕМІ ПІСЛЯДИПЛОМНОЇ ОСВІТИ
}

У статті розкривається методика розвитку методичної компетентності викладачів військовоспеціальних дисциилін (далі - викладачів ВСД) у системі післядипломної освіти, яка включає конкретні uุiлi, принциип та етапи, цілеспрямовано скомпоновані та найбільш раціональні й доцільні для кожного $з$

етапів методи, способи, прийоми, форми, засоби та зміст, які тісно пов'язані, взаємозумовлені та

сприяють розвитку їх методичної компетентності. В основу методики покладені як існуючі

компоненти педагогічного зростання викладачів ВСД, так і інноваційні складові, які у системному поєднанні сприяють иілеспрямованому розвитку методичної компетентності.

Ключові слова: викладач військово-спеціальних дисциплін, етапи, методика розвитку, методична компетентність, принципи, система післядипломної освіти.

Постановка проблеми у загальному вигляді та іï зв'язок із важливими науковими i практичними завданнями. Нині в основу функціонування провідних ВВНЗ покладено ідею професіоналізації освітнього процесу взагалі та щодо підготовки та підвищення кваліфікації викладачів ВСД як його суб'єктів, зокрема. Зазначене переконливо свідчить про нагальну потребу у викладачах ВСД з високим рівнем методичної компетентності, які знають, володіють та використовують кращі як вітчизняні, так і іноземні методики, технології, методи, засоби навчання щодо вивчення ВСД у процесі підготовки слухачів (курсантів); постійно підвищують рівень і якість власних методичних знань; запроваджують в педагогічній процес освітні й наукові інновації; вносять своєчасні, суттєві та якісні зміни до змісту підготовки слухачів (курсантів).

Практика свідчить, що нині існує три варіанта призначення офіцерів на посади викладачів ВСД - 3 посад у військах, після набуття освіти в ад’юнктурі за різними напрямами підготовки зокрема та за спеціальністю "Педагогіка вищої військової школи" взагалі. При цьому, у першому випадку офіцери майже не мають уявлення щодо організації педагогічної діяльності, у другому - певні уявлення щодо організації освітньої діяльності у ВВНЗ та незначний педагогічний досвід викладання. У останньому для їх підготовки необхідний тривалий час і кількість викладачів, які призначаються на посади викладачами ВСД незначна. Переважна більшість призначень на посади викладачів ВСД здійснюється 3 непедагогічних посад, що відповідає напрямку 3 "професіоналізації підготовки". Характерною особливістю викладачів ВСД щодо здійснення методичної діяльності є наявність значного всебічного практичного досвіду, володіння на високому рівні знаннями, навичками та уміннями у військовопрофесійній сфері, але, на жаль, має місце відсутність у переважної більшості з них педагогічної освіти та як наслідок - брак методичних знань, навичок, умінь і здатностей як педагогів.

Постає певна невідповідність між потребою ВВНЗ у викладачах ВСД з розвиненою методичною компетентністю та наявним ії̈ незадовільним станом.

Аналіз основних досліджень і публікацій із зазначеної проблеми. Особливості професійного зростання та розвиток професійної компетентності педагогів у процесі підвищення кваліфікації в системі післядипломної педагогічної освіти присвячені праці таких вітчизняних учених, як Г. Сльнікова, I. Зязюн, В. Маслов, Л. Набока, Н. Ничкало, В. Олійник, В. Пікельна, О. Пєхоти, Н. Протасова, Л. Пуховська, В. Семиченко, С. Сисоєва, Т. Сущенко Н. Тарасевич та ін.

Професійно-педагогічну компетентність педагогів досліджували О. Дубасенюк, Р. Ваврик, I. Гришина, О. Коваленко, А. Маркова, М. Кришталь, Н. Кузьміна, К. Устеміров, О. Юртаєва та ін. Різним аспектам дослідження методичної компетентності педагогів присвячені праці багатьох науковців (О. Бігич, Н. Грицай, Т. Гущина, О. Ігна, Т. Загривна, В. Земцова, О. Зубков, Т. Кочарян, І. Левченко, М. Михнюк, А. Мормуль, Л. Олійник, Н. Стефанова, Т. Сясіна, Т. Сидоренко, С. Татаринцева, О. Тумашова, В. Шаган та ін.).

Водночас, аналіз психолого-педагогічних і методичних джерел показує, що проблема методики розвитку методичної компетентності саме викладачів ВСД та іiі підвищення залишається недостатньо висвітленою та потребує педагогічного обгрунтування.

Мета статті - обгрунтування авторської методики розвитку методичної компетентності викладачів ВСД у системі післядипломної освіти.

Виклад основного матеріалу з обгрунтуванням отриманих наукових результатів. Як правило, під методикою розуміють сукупність методів і послідовність дій щодо досягнення мети. На думку 
С. У. Гончаренка, "...методика розв'язує три основних завдання й шукає відповіді на три запитання: чого навчати? Як навчати? Як учитися?" [1: 14]. В. В. Ягупов під методикою розуміє конкретні форми та засоби використання методів, за допомогою яких здійснюється все більш глибоке пізнання різноманітних педагогічних проблем та їх розв'язання [2: 357].

Теоретичний аналіз та узагальнення результатів досліджень і проблеми підвищення методичної компетентності викладачів ВСД у цілому дозволяє визначити основні чинники поліпшення умов іiі розвитку, до яких потрібно віднести визначення конкретних результатів та шляхів їх оптимального досягнення; системність, безперервність, поступовість і моделювання їх підготовки; наявність сучасного методичного забезпечення та супроводження; наполеглива самоосвітня діяльність.

Методика має відповідати таким вимогам: "концептуальності (має спиратися на певну наукову концепцію, що включає філософський, дидактичний і соціально-педагогічний аспекти досягнення цілей); системності (у ній мають чітко простежуватися всі ознаки системи - логіка процесу, взаємозв'язки його частин, цілісність); керованості (передбачає можливість діагностичного цілепокладання, проектування процесу навчання, поетапної діагностики, варіювання засобами і методами 3 метою коригування результату); ефективності (має бути ефективною за результатами та оптимальною за витратами, гарантувати досягнення певного стандарту); відтворюваності (мати можливість застосування, повторення іншими)" [3: 86].

Запропонована нами методика розвитку методичної компетентності викладачів ВСД у ВВНЗ являє собою методичну систему, яка базується на провідних ідеях компетентнісного підходу та концепції суб'єктно-діяльнісного навчання, включає конкретні цілі, принципи та етапи, цілеспрямовано скомпоновані та найбільш раціональні й доцільні для кожного $з$ етапів методи, способи, прийоми, форми, засоби та зміст, які тісно пов'язані, взаємозумовлені та сприяють розвитку їх методичної компетентності.

Методика розвитку методичної компетентності має сприяти вирішенню ієрархії таких педагогічних завдань: розвитку їх внутрішньої мотивації до здійснення методичної діяльності та позитивному сприйняттю вимог щодо іiі здійснення; формуванню культури цілеспрямованої самостійної роботи; впровадженню в подальшу педагогічну діяльність інтерактивних педагогічних технологій; використанню практико-орієнтованих, суб’єктно-діяльнісних технологій і методик фахової підготовки; моделюванню елементів методичної діяльності шляхом створення квазіпрофесійних ситуацій; координації та узгодженню змісту навчання відповідно до педагогічної діяльності; допомозі у розробленні навчальнометодичного забезпечення занять; цілеспрямованому поетапному розвитку методичної компетентності. Ці завдання визначають змістовні аспекти ії розвитку.

Для реалізації поставлених завдань на всіх етапах нам необхідно дотримуватись як загальних, так $\mathrm{i}$ спеціальних дидактичних принципів, які базуються на особливостях їх діяльності. До основних принципів розвитку методичної компетентності, на нашу думку, потрібно віднести такі загальні принципи: принципи навчання, що обслуговують усі компоненти дидактичного процесу; принципи, що стосуються діяльності суб'єктів викладання та їхньої методики педагогічної діяльності; принципи, що стосуються пізнавальної діяльності суб'єктів учіння; принципи, пов'язані 3 контрольно-оцінюючими функціями дидактичного процесу [2: 76].

Наявна система післядипломної освіти викладачів ВСД передбачає організоване й систематичне навчання військових фахівців з метою подолання розриву між здобутою ними у ВВНЗ військовопрофесійною підготовкою, набутим практичним досвідом і поставленими перед ними вимогами стосовно організації та здійснення педагогічної діяльності з урахуванням змін, що відбуваються в сучасній освіті, науці та у військовій справі. Це завдання досягається розвитком їх професійно-педагогічної компетентності шляхом поглиблення і розширення професійних знань, умінь і навичок, набуттям досвіду виконання додаткових методичних задач і завдань. Система післядипломної освіти педагогів складається з довгострокових і короткострокових курсів підвищення кваліфікації та стажування.

Нами визначено чотири рівні розвиненості методичної компетентності викладачів ВСД, а саме адаптаційний, репродуктивний, професійний і творчий [4: 3-5]. При цьому, величина часу перебування на педагогічній посаді нами автоматично не дорівнювалась до рівня розвиненості їх методичної компетентності. Той факт, що викладач певний термін перебував на посаді не є запорукою того, що він автоматично досяг певного рівня методичної компетентності. На думку авторів підручника "Педагогічна майстерність", "...педагогічний талант може і не виявитися, якщо вчитель не усвідомлює, задля чого він працює, куди спрямовані його зусилля, тобто не розуміє суті й технології педагогічної діяльності" [5: 4].

Зміст підготовки викладачів ВСД має відповідати рівню розвиненості у них методичної компетентності, тобто містити певну кількість теоретичних знань 3 питань організації освітньої діяльності, організації і здійснення методичної роботи, організації самоосвіти, здійснення рефлексії, і все це у поєднанні із здійсненням практичної педагогічної діяльності. При цьому, зміст цієї підготовки має відповідати складності завдань як на поточному рівні, так і масштабу перспективних завдань, що стоять або стоятимуть у подальшому перед викладачем ВСД на наступних рівнях. Рівень змістовної частини 
має сприяти особистісному і професійному розвитку викладачів ВСД, відповідати їх потребам, життєвим і військово-професійним цінностям, актуалізувати їхню мотиваційну сферу, стимулювати пізнавальні процеси, ставити нові завдання перед ними для творчої самоактуалізації у військово-професійній, а головне - методичній діяльності.

Власні спостереження та теоретичний аналіз психолого-педагогічної та методичної літератури дозволили визначити етапи, які освоюе викладач ВСД у системі післядипломної освіти на шляху підвищення власної компетентності до становлення суб’єктом методичної діяльності.

Запропоновані нами етапи містять відмінності, які зумовлені як цілями, які постають перед викладачами ВСД, рівнем психолого-педагогічних, методичних знань, умінь і навичок, якими вони вже володіють, так і рівнем складності методичних завдань, тобто вони відрізняються як за метою, структурою, змістом, обсягом методичних знань, умінь і навичок, якими потрібно володіти, так i професійною позицією та акмеологічними інваріантами викладача ВСД.

Програма довгострокового підвищення кваліфікації спрямована на оновлення та поглиблення викладачами ВСД спеціальних фахових, науково-методичних, педагогічних, соціально-гуманітарних, психологічних, правових, економічних та управлінських видів компетентностей, у тому числі вивчення вітчизняного та зарубіжного досвіду, що сприяє якісному виконанню педагогічної діяльності.

Підвищення кваліфікації на довгострокових курсах здійснюється для двох категорій викладачів ВСД.

У першому випадку для викладачів ВСД, які не навчалися в ад'юнктурі ВВНЗ та мають педагогічний стаж до трьох років, в обсязі 432 годин (286 годин на заняття під керівництвом викладача, 146 годин на самостійні заняття) і складається з 8 тем. Характерною особливістю здійснення цього курсу є однорідний підбір навчальної групи та схожі для викладачів ВСД методичні ускладнення та труднощі щодо здійснення методичної діяльності. До змісту курсу включений той матеріал, який, по-перше, у більшості своїй невідомий викладачам ВСД навчальної групи, а по-друге, конче необхідний їм для педагогічної діяльності.

Перший етап - ввідний (здійснюється введення викладачів ВСД до курсу шляхом проведення ввідної лекції; проводиться вхідне анкетування, за результатами якого визначається наявний рівень розвиненості методичної компетентності, з'ясовуються наявні методичні проблеми та ускладнення, які виникають у викладачів ВСД у ході методичної діяльності та виходячи з чого побудова їх траєкторії методичного розвитку на усіх етапах навчання в межах керованого, штучно і цілеспрямовано створеного навчального простору; здійснюється усвідомлення власної позиції у якості тих, хто вчиться; активізується особистісна позиція викладачів ВСД щодо професійно-педагогічного розвитку під час підвищення кваліфікації; розвивається у них позитивна мотивація до безперервної педагогічної освіти; стимулюється їх професійне самозростання.

Другий етап - навчальний: забезпечується поглиблення теоретичних і практичних знань із питань педагогіки та психології вищої військової школи (ВВШ), методики викладання у ВВШ, ораторського мистецтва, педагогічної майстерності викладача ВВН3, актуальних проблем застосування Збройних сил України, набуття нових і вдосконалення набутих раніше умінь щодо виконання педагогічних функцій, за темами: "Філософія освіти" (47 год.); "Актуальні питання педагогіки ВВШ" (126 год.); "Методика викладання фахових дисциплін у ВВН3" (30 год.); "Реалізація наукової функції науково-педагогічними працівниками ВВН3" (18 год.); "Актуальні питання психології ВВШ" (50 год.); "Педагогічна майстерність викладача ВВШ" (75 год.); Ораторське мистецтво викладача (39 год.); "Актуальні проблеми застосування Збройних Сил України" (32 год.). Вивчення змісту навчальної план-програми здійснюється шляхом проведення лекційних, групових, семінарських і практичних занять, круглих столів, а також самостійних занять слухачів із навчальним матеріалом. Перевірка якості підготовки слухачів здійснюється під час поточного і підсумкового контролю. Поточний контроль проводиться на початку всіх видів занять у формі: контрольних опитувань, летючок, бесід з окремих питань.

Третій етап - підсумковий. Здійснюється підсумковий контроль шляхом проведення комплексного екзамену за всією програмою навчання, під час якого визначається рівень засвоєння навчальної планпрограми. Викладачам ВСД, які пройшли підсумковий контроль, видається документ про отриману післядипломну освіту. Крім того, проводиться підсумкове анкетування викладачів ВСД. За результатами підсумкового контролю та анкетування представниками науково-методичного центру організації освітньої діяльності з'ясовується рівень розвиненості методичної компетентності викладачів ВСД за результатами навчання, робляться висновки щодо потреби у корекції змісту план-програми курсів, надаються рекомендації викладачам ВСД щодо подальших шляхів розвитку у міжкурсовий період їх професійно-педагогічної компетентності та ії складової - методичної.

У другому випадку для викладачів ВСД, які мають педагогічний стаж більше 3 років, проводяться заняття в обсязі 216 годин (144 години на заняття під керівництвом викладача, 72 години на самостійні заняття) 37 тем. Характерною особливістю здійснення цього курсу є неоднорідний підбір навчальної групи і виходячи з чого, можливий різний рівень розвиненості у них методичної компетентності, що потрібно враховувати під час навчання. 
Перший етап - ввідний (здійснюється доведення до викладачів ВСД інформації щодо курсу проведення ввідної лекції; проведення вхідного анкетування, за результатами якого визначається наявний рівень розвиненості методичної компетентності, з'ясовуються наявні методичні проблеми та ускладнення, які виникають у викладачів ВСД у ході методичної діяльності та виходячи 3 чого відбувається побудова кожним викладачем ВСД власної траєкторії методичного розвитку на усіх етапах навчання в межах керованого, штучно і цілеспрямовано створеного навчального простору; здійснюється усвідомлення власної позиції в якості тих, хто вчиться; активізується особистісна позиція викладачів ВСД щодо професійно-педагогічного розвитку під час здійснення підвищення кваліфікації; стимулюється їх професійне самозростання, формуються професійні наміри щодо підвищення своєї професійно-педагогічної компетентності.

Другий етап - навчальний. До змісту курсу включений матеріал, який забезпечує у них оновлення та поглиблення теоретичних і практичних знань із питань педагогіки та психології ВВШ, методики викладання у ВВШ, ораторського мистецтва, педагогічної майстерності викладача ВВНЗ, ефективного поєднання на практиці теоретичних знань 3 інноваційними педагогічними методиками й технологіями, актуальних питань забезпечення життєдіяльності Збройних Сил України, набуття нових та удосконалення набутих раніше умінь щодо виконання педагогічних функцій за такими темами: "Актуальні проблеми сучасної філософії освіти" (14 год.); "Актуальні питання педагогіки ВВШ" (56 год.); "Актуальні питання психології ВВШ" (42 год.); "Методика викладання фахових дисциплін у ВВНЗ" (15 год.); "Педагогічна майстерність викладача ВВНЗ" (39 год.); "Ораторське мистецтво викладача ВВШ" (22 год.); "Актуальні питання забезпечення життєдіяльності ЗС України" (12 год.). Вивчення змісту навчальної план-програми здійснюється шляхом проведення лекційних, групових, семінарських i практичних занять, круглих столів, а також самостійних занять слухачів із навчальним матеріалом. Перевірка якості підготовки слухачів здійснюється під час поточного і підсумкового контролю. Поточний контроль проводиться на початку всіх видів занять у формі: контрольних опитувань, летючок, бесід з окремих питань.

Третій етап - підсумковий, на якому здійснюється підсумковий контроль шляхом проведення комплексного екзамену за всією програмою навчання для визначення рівнів засвоєння навчальної планпрограми. Викладачам ВСД, які пройшли підсумковий контроль, видається документ про отриману післядипломну освіту. Крім того, проводиться підсумкове анкетування. За результатами підсумкового контролю та анкетування представниками науково-методичного центру організації освітньої діяльності 3'ясовується рівень розвиненості методичної компетентності викладачів ВСД за результатами навчання, робляться висновки щодо потреби у корекції змісту план-програми курсів, надаються рекомендації викладачам ВСД щодо подальших шляхів розвитку у міжкурсовий період професійно-педагогічної компетентності та її складової - методичної.

Навчання на короткострокових курсах підвищення кваліфікаиії здійснюється шляхом проведення семінарів, семінарів-практикумів, семінарів-нарад, семінарів-тренінгів, тренінгів, вебінарів, "круглих столів" тощо та передбачає комплексне вивчення сучасних та актуальних наукових проблем у галузі освіти, науки, педагогіки, відповідних нормативно-правових актів, вітчизняного та зарубіжного досвіду, підвищення рівня професійної культури тощо [5; 6].

Стажування здійснюється з метою розвитку і закріплення на практиці професійної компетентності здобутої у результаті теоретичної підготовки щодо виконання завдань і обов’язків на займаній посаді або посаді вищого рівня, засвоєння вітчизняного та зарубіжного досвіду, формування особистісних якостей для виконання професійних завдань на новому, більш високому якісному рівні в межах певної спеціальності. Стажування може здійснюватися: на власній базі ВВНЗ; на споріднених кафедрах та інститутах ВНЗ аналогічного профілю або ВВНЗ (ВНП ВНЗ) міста, країни; в органах військового управління, військових частинах (на кораблях), на підприємствах, в організаціях, установах Міністерства оборони України; на підприємствах, в організаціях та установах інших центральних органів виконавчої влади.

Стажування викладачів ВСД у військах (силах) проводиться з метою: удосконалення їх військовопрофесійних знань і навичок зі спеціальності на відповідних командних, штабних, інженерних та інших посадах; вивчення для використання в освітньому процесі передового досвіду оперативної, бойової та мобілізаційної підготовки військ (сил) і служби випускників ВВНЗ (ВНП ВНЗ) у військах (силах); надання допомоги військам (силам) у впровадженні в їх практичну діяльність передових методів навчання і виховання, результатів наукових досліджень [5].

Перший етап - підготовчий. На основі перспективного план-графіку підвищення кваліфікації (стажування) розробляється план стажування викладачів ВСД на календарний рік та узгоджується 3 ВВН3 (органами військового управління, підприємствами) на базі якого планується проведення стажування. У ВВНЗ з урахуванням сучасних вимог до викладачів ВСД складається індивідуальний навчальний план стажування, в якому розкриваються завдання стажування, визначаються, що нового він має дослідити та вивчити 3 метою подальшого запровадження в ВВНЗ (інституту, кафедри) за 
результатами стажування. Тематика завдань стажування визначається викладачам ВСД відповідно до навчальних дисциплін, які вони викладають.

Другий етап - основний. Здійснення власне стажування викладачів ВСД, яким відповідно до завдання та теми стажування призначається консультант із числа провідних фахівців закладу. Консультант забезпечує необхідні умови для проходження стажування, спільно із викладачем ВСД уточнює індивідуальний план роботи та контролює його виконання, бере участь у підведенні підсумків стажування. Стажування сприяє закріпленню знань, умінь, навичок, необхідних викладачу ВСД в процесі педагогічної та науково-дослідницької діяльності, дає можливість набути сучасний передовий досвід, допомагає встановленню взаємодії та співпраці між навчальними закладами, сприяє вивченню передового досвіду і набуттю професійних та організаторських навичок для виконання обов'язків займаної ним чи вищої посади. Стажування забезпечує поєднання теоретичного матеріалу з практичною діяльністю у вирішенні конкретних педагогічних задач і завдань. Програма стажування викладачів ВСД може передбачати такі завдання самоосвітньої діяльності: ознайомлення з науково-методичною базою кафедр ВНЗ (університету, інституту тощо); аналіз навчально-методичної бази підрозділу, де проходить стажування; відвідування навчальних занять провідних викладачів за темою стажування (вивчення педагогічного досвіду, ознайомлення з методикою організації й проведення всіх видів навчальних занять провідними педагогами); ознайомлення та участь у процесі розроблення сучасних засобів навчання, набуття нового досвіду щодо застосування сучасних інформаційних технологій у навчанні; вивчення навчально-методичного забезпечення освітнього процесу; екскурсії до провідних установ і підприємств тощо.

Третій етап - заключний. Після закінчення стажування викладач ВСД готує звіт про виконання індивідуального плану стажування та доповідь про отримані результати на засіданні кафедри (центру).

Міжкурсова підготовка викладачів ВСД у системі післядипломної освіти педагогів охоплює період між проходженнями ними довгострокових і короткострокових курсів підвищення кваліфікації та стажування. Спираючись на вивченні керівні документи, дослідження науковців, власний емпіричний досвід, форми розвитку методичної компетентності викладачів ВСД під час здійснення заходів міжкурсової підготовки можна поділити на такі: на рівні науко-методичної роботи ВВНЗ (інституту), на рівні науково-методичної роботи кафедри, на рівні самоосвіти; індивідуальна самоосвітня робота; самонавчання; самооцінювання власних видів методичної діяльності; здобуття наукового ступеня, участь у науково-дослідних роботах, написання фахових статей, консультування; самоспостереження, самокритика тощо. Заходи міжкурсової підготовки у системі науково-методичної роботи університету (інституту), у системі методичної роботи кафедри та у самоосвітній діяльності неоднакові. Головною відмінністю $\epsilon$ рівень включення викладача до діяльності. Крім того, різниться змістовна та праксиологічна частина, виходячи від поточного рівня розвитку знань, умінь і навичок, якими вже володіє викладач ВСД, та складності методичних завдань, які він виконує.

Під час здійснення навчання у системі післядипломної освіти нами використані як традиційні, так i інноваційні форми та методи розвитку методичної компетентності викладачів ВСД. Важливим є те, що ефективний розвиток методичної компетентності викладачів ВСД передбачає впровадження взаємопов'язаного комплексу традиційних та інноваційних форм, методів i засобів розвитку їх методичної компетентності. До традиційних ми відносимо такі форми, як: самоосвіта, наставництво, лекції, групові, семінарські та практичні заняття, педагогічні читання, конференції, курси підвищення кваліфікації, стажування, школи молодого викладача, школи передового методичного досвіду, тощо; до інноваційних - конкурс професійної майстерності; спецкурс "Методична компетентність молодого викладача ВСД", мережевий проект "Сайт методичної підтримки викладачів ВСД" тощо.

Здійснення розвитку методичної компетентності викладачів ВСД у системі післядипломної освіти передбачає системне застосування у методичній підготовці активних і традиційних методів навчання.

Центральне місце в розвитку методичної компетентності відведено самому викладачу ВСД, як стрижневому цієї методики. Індивідуальна самоосвітня робота викладачів ВСД є основною формою розвитку їх методичної компетентності. Розвиток методичної компетентності викладачів ВСД у самоосвітній діяльності реалізує такі завдання: розширення і поглиблення методичних знань, умінь, навичок; вдосконалення індивідуального стилю методичної діяльності; розвиток інтелектуальних якостей і розумових здатностей; забезпечення професійної самореалізації тощо. Формами і методами самовдосконалення визначено: самонавчання, самооцінювання власного рівня методичної компетентності, консультування; самоспостереження, самокритику, рефлексію тощо. Однією із важливих умов забезпечення успішної самоосвітньої роботи є методичний супровід індивідуальної траєкторії розвитку методичної компетентності викладачів ВСД. Для цього здійснюється вивчення й аналіз діяльності за допомогою таких методів, як спостереження, бесіда, анкетування, ранжування, експертне оцінювання тощо за відповідними критеріями і показниками [8: 116-119].

Під час проходження заходів у системі післядипломної освіти має здійснюватись систематичне діагностування результатів розвиненості методичної компетентності викладачів ВСД. Так, вхідне 
діагностування необхідно проводити 3 метою визначення рівнів розвиненості їх методичної компетентності, вибору найкращих форм, методів, методик, технологій і засобів ії розвитку. Таке діагностування може здійснюватися у вигляді тестування, оцінювання практичних здатностей, складання звітних матеріалів тощо. Діагностування когнітивної складової розвиненості методичної компетентності викладачів ВСД має здійснюватися переважно у формі індивідуального письмового завдання, їм мають пропонуватися контрольні випробування у формі як закритих (із заданими варіантами відповідей), так i відкритих питань. Діагностування праксеологічної складової методичної компетентності викладачів ВСД здійснюється під час виконання педагогічної діяльності шляхом експертної оцінки навчальнометодичних матеріалів, проведенням контрольних заходів і взаємовідвідувань навчальних занять, тощо.

Висновки. Отже, у результаті реалізації запропонованої методики у викладачів ВСД відбуваються такі позитивні зміни: 1) розвивається внутрішня мотивація та позитивне ставлення до здійснення методичної діяльності; 2) здійснюється об'єктивний контроль й оцінювання рівнів розвиненості власної методичної компетентності; 3) здійснюється цілеспрямований поетапний розвиток методичної компетенції, та як результат, підвищується рівень педагогічної діяльності; 4) відбувається прояв себе - як суб'єкта методичної діяльності.

Отже, таку комплексну методику можна вважати досить ефективною та її можна творчо адаптувати для підвищення методичної компетентності викладачів ВСД у системі післядипломної освіти 3 урахуванням специфіки їх підготовки.

Перспективи подальшого дослідження проблеми. Удосконалення методики оцінювання розвиненості методичної компетентності викладачів ВСД у системі післядипломної освіти.

\section{СПИСОК ВИКОРИСТАНИХ ДЖЕРЕЛ ТА ЛІТЕРАТУРИ}

1. Гончаренко С. У. Методика як наука / С. У. Гончаренко. - Хмельницький : Вид-во ХГПК, 2000. - 30 с.

2. Ягупов В.В. Військова дидактика : [навч. посіб.] / В. В. Ягупов. - К. : ВПЦ "Київський університет", 2000. $400 \mathrm{c}$.

3. Селевко Г. К. Современные образовательные технологи : [учеб. пособие] / Г. К. Селевко. - М. : Народное образование, 1998. - 256 с.

4. Остапенко В. С. Диагностирование уровней развития методической компетентности преподавателей военноспециальных дисциплин в высших военных учебных заведениях / В. С. Остапенко // Научно-теоретический и практический журнал "Современный научный вестник". - № 42 (238), г. Белгород, 2014. - С. 5-12.

5. Педагогічна майстерність : [підручник для вищих пед. навч. закладів] / За ред. І. А. Зязюна. - К. : Вища школа, 1997. - 349 с.

6. Наказ Міністерства оборони України №346 від 20.07.2015 "Про затвердження Положення про особливості організації освітнього процесу у вищих військових навчальних закладах Міністерства оборони України та військових навчальних підрозділах вищих навчальних закладів України" [Електронний ресурс]. - Режим доступу : http://zakon.rada.gov.ua/laws/show/z1126-15.

7. Наказ Міністерства і науки, молоді та спорту України №48 від 24.01.2013 "Про затвердження Положення про підвищення кваліфікації та стажування педагогічних і науково-педагогічних працівників вищих навчальних закладів" [Електронний ресурс]. - Режим доступу : http://zakon.rada.gov.ua/laws/show/z0488-13.

8. Остапенко В. С. Критерії та показники діагностування рівнів розвиненості методичної компетентності викладачів військово-спеціальних дисциплін у вищих військових навчальних закладах / В. С. Остапенко // Вісник Національного університету оборони України. - Вип. 4 (35). 2013. - С. 114-119.

\section{REFERENCES (TRANSLATED \& TRANSLITERATED)}

1. Honcharenko S. Yu. Metodyka yak nauka [Methodology as a Science]/ S. Yu. Honcharenko. - Khmelnytskyi : Vyd-vo KhHPK, 2000. - 30 s.

2. Yahupov V. V. Viis'kova dydaktyka [Military Didactics] : [navch. posib.] / V. V. Yahupov. - K. : VPTs "Kyivs'kyi universytet", 2000. $-400 \mathrm{~s}$.

3. Selevko G. K. Sovremennyie obrazovatel'nyie tekhnologii [Modern Educational Technology] : [ucheb. posobie] / G. K. Selevko. - M. : Narodnoie obrazovaniie, 1998. - $256 \mathrm{~s}$.

4. Ostapenko V.S. Diagnostirovaniie urovnei razvitiia metodicheskoi kompetentnosti prepodavatelei voiennospecial'nykh distsiplin v vysshykhh voiennykh uchebnykh zavedeniiakh / V. S. Ostapenko // Nauchno-teoreticheskii i prakticheskii zhurnal "Sovremennyi nauchnyi vestnik" [Scientific-Theoretical and Practical Journal "Modern Scientific Herald"]. - № 42 (238), g. Belgorod, 2014. - S. 5-12.

5. Pedahohichna maisternist' [Pedagogical Skill] : [pidruchnyk dlia vyshchykh ped. navch. zakladiv] / Za red. I. A. Ziaziuna. - K. : Vyshcha shkola, 1997. - 349 s.

6. Nakaz Ministerstva oborony Ukrainy №346 vid 20.07.2015 Pro zatverdzhennia Polozhennia pro osoblyvosti orhanizatsii osvitnioho protsesu u vyshchykh viis'kovykh navchal'nykh zakladakh Ministerstva oborony Ukrainy ta viis'kovykh navchal'nykh pidrozdilakh vyshchykh navchal'nykh zakladiv Ukrainy [Order of the Ministry of Defense of Ukraine № 346 Dated July 20, 2015 "On Approval of the Regulation on the Peculiarities of the Organization of the Educational Process in Higher Military Educational Institutions of the Ministry of Defense of Ukraine and Military Educational Subdivisions of Higher Educational Institutions of Ukraine"]. - Rezhym dostupu: http://zakon.rada.gov.ua/laws/show/z1126-15. 
7. Nakaz Ministerstva i nauky, molodi ta sportu Ukrainy №48 vid 24.01.2013 Pro zatverdzhennia Polozhennia pro pidvyshchennia kvalifikatsii ta stazhuvannia pedahohichnykh i naukovo-pedahohichnykh pratsivnykiv vyshchykh navchal'nykh zakladiv [Order of the Ministry of Science and Youth of Ukraine № 48 Dated January 24, 2013 "On Approval of the Regulations for the Upgrading of Qualifications and Internship of Teachers and Teachers of Higher Educational Institutions"] [Elektronnyi resurs]. - Rezhym dostupu : http://zakon.rada.gov.ua/laws/show/z0488-13.

8. Ostapenko V.S. Kryterii ta pokaznyky diahnostuvannia rivniv rozvynenosti metodychnoi kompetentnosti vykladachiv viis'kovo-spetsial'nykh dystsyplin u vyshchykh viiskovykh navchal'nykh zakladakh [The Diagnostic Criteria and Data of Levels of the Methodological Competence Development of the Teachers of Special Military Subjects in Higher Military Educational Institutions] / V. S. Ostapenko // Visnyk Natsional'noho universytetu oborony Ukrainy [Bulletin of the National Defense University of Ukraine]. - Vyp. 4 (35). 2013. - S. 114-119.

\section{Остапенко В. С. Методика развития методической компетентности преподавателей военно- специальных дисциплин в системе последипломного образования.}

В статье раскрывается методика развития методической компетентности преподавателей военноспециильных дисциплин в системе последипломного образования, которая включает конкретные цели, приниииы и этапы, целенаправленно скомпонованные и наиболее рациональные и целесообразные для каждого из этапов методы, способы, приемы, формы, средства и содержсание, которые тесно связаны, взаимообусловлены и способствуют развитию их методической компетентности. В основу методики

положены как существующие компоненты педагогического роста преподавателей ВСД, так $и$ инновационные составляющие, которые в системном сочетании способствуют иеленаправленному развитию методической компетентности.

Ключевые слова: преподаватель военно-специальных дисциплин, этапь, методика развития, методическая компетентность, принципы, система последипломного образования.

\section{Ostapenko V. S. Methodology of Methodical Competence Development of Teachers of Military Special Disciplines in the System of Postgraduate Education.}

The article proposes to eliminate the inconsistency between the needs of the secondary education school in the teachers of military special disciplines with advanced methodological competence and its current state by using the proposed author's methodology for the development of their methodological competence in the system of postgraduate education. It is substantiated that author's technique is a methodical system based on the leading ideas of the competence approach and the concept of subject-activity training, which includes specific goals, principles and stages, purposefully designed and most rational and expedient for each of the stages methods,

techniques, forms, means and content that are closely interconnected, interdependent and promote the development of their methodological competence. The methodology is based on the existing components of the pedagogical growth of the teachers of military special disciplines in the system of postgraduate education, as well as the innovative components that in the system combine contribute to the purposeful development of an integral professional-important component of military-professional competence-methodological. There are four levels of development of methodical competence of teachers of military special disciplines, namely adaptive, reproductive, professional and creative. Achievement of these levels in the system of postgraduate education occurs at appropriate stages. An important part of the realization of the tasks at all stages of the development of methodical competence of the teachers of military special disciplines is the need to adhere to both general and special didactic principles, which are based on the peculiarities of their methodological activity. As a result of the implementation of the proposed method, the following positive changes have been made to the teachers of

military special disciplines: internal motivation and positive attitude toward methodological activity are developing; objective control and evaluation of levels of development of own methodical competence are carried out; there is a purposeful stage-by-stage development of methodical competence and, as a result, the quality of pedagogical activity increases.

Key words: teacher of military special disciplines, stages, methods of development, methodical competence, principles, system of post-graduate education. 